ljtihad, Jurnal Wacana Hukum Islam dan Kemanusiaan

Vol. 16, No. 2 (2016), pp. 217-236, doi : 10.18326/ijtihad.v16i2.217-236

\title{
Kinerja reksa dana syariah dan beberapa faktor yang memengaruhinya: studi di pasar modal Indonesia 2010-2013
}

\author{
Setia Mulyawan \\ UIN Sunan Gunung Djati Bandung \\ E-mail:setiamulyawan@uinsgd.ac.id \\ DOI: 10.18326/ijtihad.v16i2.217-236
}

The purpose of this study was to determine the effect of the characteristics on the performance of Islamic mutual funds in Indonesia. By analyzing data from 27 Islamic mutual funds traded on the Indonesia Stock Exchange during the 48 months (January 2010-December 2013), and using panel data as a technical analysis, the study came to the conclusion that the characteristics of Islamic mutual funds, represented by the turnover ratio, expenses ratio, fund size, fund age, and fund selection influence the performance of Islamic mutual funds in Indonesia. Turnover ratio, fund size, fund age, and fund selection have positive effect to the performance of Islamic mutual fund.

Penelitian ini bertujuan untuk mengetahui pengaruh karakteristik terhadap kinerja reksa dana syariah di Indonesia. Dengan menganalisis data 27 reksa dana syariah yang diperdagangkan di Bursa Efek Indonesia selama 48 bulan (Januari 2010-Desember 2013), dan menggunakan metode data panel sebagai teknis analisis, diperoleh kesimpulan bahwa karakteristik reksa dana syariah yang diwakili oleh turnover ratio, expenses ratio, fund size, fund age, dan fund selectionmerupakan beberapa faktor berpengaruh terhadap kinerja reksa dana syariah. Turnover ratio, fund size,fund age, danfund selection berpengaruh positif, sedangkan expenses ratio berpengaruh negatif terhadap kinerja reksa dana syariah

Keywords: Characteristics; Performance; Islamic mutual funds; Financial markets

\section{Pendahuluan}

Sebagai pasar modal negara berkembang (emerging market), Bursa Efek Indonesia (BEI) memiliki tingkat pertumbuhan transaksi instrumen keuangan syariah yang cukup tinggi. Meskipun masa perkembangannya relatif baru dibandingkan dengan perbankan syariah 
ljtihad, Jurnal Wacana Hukum Islam dan Kemanusiaan, Volume 16, No. 2, Desember 2016: 217-236

dan asuransi syariah, tetapi seiring dengan pertumbuhan industri pasar modal Indonesia, investasi pada instrumen keuangan syariah di pasar modal Indonesia telah mengalami pertumbuhan yang pesat. Kehadiran instrumen keuangan syariah di pasar modal Indonesia telah memberikan kontribusi terhadap perekonomian negara. Banyak perusahaan dari sektor pertanian, pertambangan, properti, real estate dan lain-lain yang menerbitkan instrumen keuangan syariah.

Salah satu jenis instrumen keuangan yang diperjualbelikan di pasar modal Indonesia adalah reksa dana. Reksa dana merupakan salah satu alternatif investasi bagi masyarakat khususnya investor kecil dan investor yang tidak memiliki banyak waktu dan keahlian untuk menghitung risiko atas investasi mereka. Reksa dana dirancang sebagai sarana untuk menghimpun dana dari masyarakat yang memiliki modal, mempunyai keinginan untuk melakukan investasi, namun hanya memiliki waktu dan pengetahuan yang terbatas. Selain itu reksa dana juga diharapkan dapat meningkatkan peran pemodal lokal untuk berinvestasi di pasar modal Indonesia. Reksa dana merupakan instrumen keuangan yang dipergunakan untuk menghimpun dana dari masyarakat pemodal untuk selanjutnya di investasikan dalam portfolio efek oleh Manajer Investasi (Undang-undang RI 8/1995 tentang Pasar Modal). Reksa dana syariah merupakan salah satu jenis reksa dana yang disediakan untuk memberikan kesempatan kepada investor yang berniat melakukan investasi pada perusahaan-perusahaan yang memenuhi kriteria dan tidak bertentangan dengan kaidah-kaidah syariah.

Penelitian ini dimaksudkan untuk memperoleh jawaban atas beberapa rumusan masalah penelitian sebagai berikut: Apakah terdapat pengaruh turnover ratio terhadap kinerja reksa dana syariah?; Apakah terdapat pengaruh expenses ratio terhadap kinerja reksa dana syariah?; Apakah terdapat pengaruh fund size terhadap kinerja reksa dana syariah?; Apakah terdapat pengaruh fund age terhadap kinerja reksa dana syariah?; Apakah terdapat pengaruh fund selection terhadap kinerja reksa dana syariah?

Tujuan penelitian ini adalah untuk memperoleh bukti empiris tentang pengaruh beberapa karakteristik reksa dana syariah yang terdiri dari turnover ratio, expenses ratio, fund size, fund age, dan fund selection terhadap kinerja reksa dana syariah di Indonesia. Hasil penelitian diharapkan dapat memberikan kontribusi kepada investor dalam mengambil keputusan investasi pada instrumen keuangan syariah. 


\section{Studi pustaka dan kerangka teori}

Reksa dana (mutual fund) merupakan sarana investasi yang dapat digunakan oleh masyarakat untuk berinvestasi dalam bentuk portofolio efek yang hasilnya tercermin dalam peningkatan nilai Nilai Aktiva Bersih (NAB). Reksa dana adalah instrumen keuangan yang dipergunakan untuk menghimpun dana dari masyarakat pemodal yang selanjutnya diinvestasikan dalam bentuk portofolio efek oleh Manajer Investasi. Reksa dana merupakan sekumpulan saham, obligasi, atau sekuritas lainnya yang dimiliki oleh kelompok investor dan dikelola oleh perusahaan investasi.Di Indonesia, reksa dana syariah diterbitkan pada tahun 1997 dua tahun setelah kelahiran Undang-undang Nomor 8 tahun 1995 tentang Pasar Modal yang antara lain menjelaskan tentang reksa dana. Reksa dana syariah yang pertama kalinya adalah reksa dana Syariah Danareksa Saham yang mulai diperdagangkan pada bulan Juli 1997.

Sebagai salah satu instrumen investasi, reksa dana syariah memiliki kriteria yang berbeda dengan reksa dana konvensional pada umumnya. Perbedaan ini terletak pada pemilihan instrumen investasi dan mekanisme investasi yang harus berpedoman pada kaidah syariah Islam. Dalam penyusunan portofolioinvestasinya, reksa dana syariah hanya dapat menempatkan dananya ke dalam instrumen-instrumen investasi yang terbebas dari riba dan praktek-praktek tidak halal menurut syariah. Pada instrumen pasar modal, reksa dana syariah hanya menempatkan dananya pada emiten atau perusahaan atau pihak-pihak penerbit instrumen investasi yang tidak melakukan usaha-usaha yang bertentangan dengan prinsip kehalalan syariah seperti riba, perjudian, pornografi, minuman haram (alkohol), babi, hiburan yang bertentangan dengan syariah, dan lain-lain. Tugas manajer investasi pada reksa dana syariah menjadi lebih luas dibandingkan dengan manajer investasi reksa dana konvensional. Selain harus menyusun strategi portofolio yang baik agar menghasilkan returnyang optimal, Manajer Investasi pada reksa dana syariah juga harus menjamin kehalalan proses investasi yang dilakukan.

Kinerja sebuah sekuritas termasuk reksa dana dipengaruhi oleh beberapa faktor baik faktor eksternal seperti keadaan perekonomian suatu negara maupun faktor-faktor yang melekat pada reksa dana itu sendiri. Dari sisi faktor yang melekat pada reksa dana itu sendiri, beberapa penelitian menunjukkan bahwa kinerja reksa dana dipengaruhi oleh karakteristik reksa dana seperti: (1) turnover ratio (Anderson, et al., 1996 ; 203, Cuthbertson, 
ljtihad, Jurnal Wacana Hukum Islam dan Kemanusiaan, Volume 16, No. 2, Desember 2016: 217-236

Nitzsche, dan O’Sullivan, 2010 ; 95), (2) expenses ratio, (Sharpe, 1966 ; 119, Malkiel, 1995 ; 549, Ciccotello dan Grant, 1996; 365, Carhart, 1997 ; 57); (3) fund size (Carlson, 1977; 1, Grinblatt dan Titman, 1989; 419, Chen, et al., 1992; 659,Ciccotello dan Grant, 1996; 365, Indro, et al., 1999; 74, Low, 2007; 29, Abassi, Kalantari, dan Abassi, 2012 ; 6889); (4) fund age (Khorana, Nelling, dan Edward, 1998; 61, Afza dan Rauf, 2009;199); (5) fund selection skill (Treynor dan Mazuy, 1966;131,Fama, 1972;551,Kon dan Jen, 1979;261, Chen, et al., 1992;659). Selain itu, hasil penelitian Paranita, Dzulkirom, dan Hidayat, (2015;1) memperoleh temuan bahwa reksa dana yang baik adalah yang mampu menghasilkan nilai positif indeks Sharpe dan Treynor serta mampu outperform dibandingkan benchmark (IHSG). Kartini dan Febriyanto (2011;1) memperoleh temuan bahwa rata-rata kinerja reksa dana saham syariah memberikan return yang lebih baik (outperform) dibandingkan kinerja pasarnya yaitu JII.Hermawan dan Wiagustini (2016;3129) menyimpulkan hasil penelitiannya bahwa bahwa inflasi berpengaruh negatif terhadap kinerja reksa dana saham. Beberapa karakteristik ini terbukti secara empiris memiliki pengaruh terhadap kinerja reksa dana.

Reksa dana yang mempunyai rasio perputaran (turnover ratio) yang tinggi menunjukkan bahwa manajer investasi melakukan aktivitas pembelian maupun penjualan portofolio dengan frekuensi tinggi, yang berarti menunjukkan tingginya trading activity reksa dana tersebut. Semakin tinggi tingkat perputaran portofolio maka semakin besar return yang mungkin didapatkan. Tingginya turnover ratio menunjukkan bahwa manajer investasi benar-benar mengantisipasi perubahan pasar seperti berbagai isu yang ada, serta kondisi ekonomi yang kemudian akan mempengaruhi harga aset dalam portofolionya. Trading activity yang tinggi menggambarkan usaha manajer investasi dalam mewujudkan return yang maksimal dengan melakukan perdagangan pada saat yang tepat. Tingkat turnover yang tinggi atau dengan istilah lain manajer investasi dengan gaya investasi aktif mewujudkan kinerja reksa dana yang lebih baik daripada manajer dengan gaya investasi pasif. Turnover ratio memiliki pengaruh yang positif terhadap kinerja reksa dana (Grinblatt dan Titman, 1989;419). Reksa dana dengan high turnover menghasilkan kinerja yang lebih baik dan reksa dana dengan low turnover menghasilkan kinerja yang lebih buruk (Grinblatt dan Titman,1994;441).

Expenses ratio merupakan perbandingan antara beban operasional pengelolaan reksa dana dengan rata-rata Nilai Aktiva Bersih (NAB). Rasio ini menunjukkan seberapa besar 
pengorbanan investor dalam melakukan investasi pada reksa dana sekaligus merupakan indikasi seberapa "mahal" manajer investasi menetapkan tarif dalam mengelola reksa dana. Expenses ratio sebuah reksa dana adalah persentase total biaya yang digunakan untuk administrasi, manajemen, iklan, dan semua biaya lainnya. Expenses ratio adalah biaya reksa dana dalam menjalankan kegiatan bisnisnya. Rasio ini penting menjadi perhatian saat investor akan memilih reksa dana karena besar kecilnya rasio ini akan turut menentukan besarnya return yang diterima oleh investor.

Fund Size dapat digambarkan oleh besaran aset yang dikelola oleh perusahaan reksa dana. Besarnya aset ini menunjukkan seberapa besar kepercayaan (trust) dari investor kepada lembaga tersebut. Aktiva sebuah perusahaan merepresentasikan besaran kekayaan yang dimiliki perusahaan tersebut. Kekayaan reksa dana dapat dilihat dari besarnya Nilai Aktiva Bersih (NAB) yang dimiliki. Kekayaan yang dimiliki perusahaan pada umumnya menunjukkan skala ekonomi suatu perusahaan. Semakin besar skala ekonomi perusahaan maka semakin besar ukuran perusahaan tersebut. Besar kecilnya suatu reksa dana akan merepresentasikan jumlah kapitalisasi pasar reksa dana tersebut. Dalam banyak penelitian yang dilakukan untuk menginvestigasi pengaruh ukuran terhadap excess return mengindikasikan bahwa ukuran yang besar akan menyebabkan risiko yang dihadapi perusahaan menjadi lebih kecil dibanding risiko yang dihadapi perusahaan yang lebih kecil (Chen, et al., 1992;659).

Fund age atauusia dari reksa dana mengindikasikan kapan suatu reksa dana mulai diperdagangkan di pasar modal. Banyak investor yang lebih menyukai reksa dana yang berumur lebih lama. Kinerja reksa dana yang baik memiliki manajer investasi yang mempunyai pengalaman lebih lama (Khorana, Nelling, dan Edward, 1998). Reksa dana dengan riskadjusted return yang positif berhubungan dengan umur reksa dana tersebut. Peningkatan usia reksa dana memungkinkan dana untuk mencapai efisiensi operasional (Afza dan Rauf, 2009;199). Reksa dana yang memiliki umur yang lebih lama akan memiliki track record yang lebih panjang, dan dapat memberikan gambaran kinerja yang lebih baik kepada para investornya. Umur reksa dana mencerminkan pengalaman dari manajer investasinya dalam mengelola reksa dana tersebut. Semakin lama umur suatu reksa dana, maka manajer investasinya semakin berpengalaman di dalam mengelola portofolio bila dibandingkan dengan reksa dana yang berumur lebih muda. 
ljtihad, Jurnal Wacana Hukum Islam dan Kemanusiaan, Volume 16, No. 2, Desember 2016: 217-236

Jensen (1968;400) membagi konsep kinerja portofolio menjadi dua dimensi, yaitu: (1) kemampuan manajer investasi atau analisis sekuritas untuk meningkatkan return portofolio melalui prediksi yang tepat tentang harga sekuritas di masa yang akan datang, dan (2) kemampuan manajer investasi untuk meminimalkan risiko (melalui diversifikasi yang efisien) yang muncul dari kepemilikan portofolio. Penggunaan kemampuan dalam memilih aset individu atau fund selection skill telah secara luas digunakan dalam karakteristik dan kinerja investasi. Fama (1972;551), menyatakan bahwa kinerja manajer investasi dapat dibedakan menjadi dua, yaitu: (1) Stock Selection Skill,yaitu kemampuan manajer investasi untuk memilih aset untuk membentuk portofolio yang diprediksi akan memberikan return yang diharapkan di masa yang akan datang. Manajer investasi lebih sering mengandalkan kemampuan pemilihan sekuritas untuk mendapatkan return yang abnormal (superior). Aktivitas stock selection didasarkan pada forecast kejadian khusus perusahaan dan harga sekuritas individu (Kon, 1983;321), dan (2) Market Timing Ability adalah kemampuan manajer investasi untuk mengambil kebijakan yang tepat untuk membeli atau menjual sekuritas tertentu untuk membentuk portofolio aset pada saat yang tepat. Sedangkan aktivitas market timing berhubungan dengan forecast realisasi di masa mendatang dari portofolio pasar. Jika manajer investasi yakin dapat menghasilkan lebih baik dari rata-rata estimasi return pasar maka manajer akan menyesuaikan tingkat risiko portofolionya sebagai antisipasi perubahan pasar (Kon, 1983;321).

Mengukur kinerja suatu portofolio umumnya terkait dengan dua isu utama, yaitu: (1) mengevaluasi apakah return portofolio yang telah dibentuk mampu memberikan return yang lebih besar dibandingkan dengan return portofolio lainnya yang dijadikan patok duga (benchmark), dan (2) mengevaluasi apakah return yang diperoleh sudah sesuai dengan tingkat risiko yang harus ditanggung. Dalam literatur manajemen investasi dan portofolio, terdapat dua metode yang digunakan untuk mengukur kinerja, yaitu metode Non Risk-Adjusted Performance dan Risk-Adjusted Performance (Tendelilin, 2010;493).

Metode Non Risk-Adjusted Performance merupakan metode mengukur kinerja portofolio dengan hanya melihat return yang diperoleh dari investasi tersebut, tanpa memasukan unsur risiko di dalamnya. Metode ini dilakukan dengan cara menjumlahkan semua aliran kas yang diterima (dividen dan atau pendapatan bunga) dengan selisih perubahan portofolio (capital gain/loss) dibagi dengan nilai pasar portofolio pada awal periode. Metode ini, meski sangat 
sederhana, namun memiliki kelemahan, yaitu tidak memasukkan faktor risiko dalam perhitungannya. Metode mengukur kinerja portofolio kemudian mengalami pengembangan dengan memasukan faktor risiko dalam perhitungannya (Risk-Adjusted Performance). Salah satu metode yang bisa dilakukan untuk mengukur kinerja portofolio adalah Indeks Treynor (Tendelilin, 2010;497).

Ukuran kinerja reksa dana dalam penelitian ini menggunakan Rasio Treynor yang dimodifikasi dengan mengganti $\mathrm{R}_{\mathrm{f}}$ dengan PP (Pertumbuhan Produksi), sehingga perhitungan kinerja reksa dana syariah dalam penelitian ini menggunakan rumus:

$$
\mathrm{TR}_{\mathrm{p}, \mathrm{t}}=\frac{\overline{\mathrm{R}_{\mathrm{i}, \mathrm{l}}}-\overline{\mathrm{PP}_{\mathrm{t}}}}{\beta_{\mathrm{pt}}}
$$

Dimana:

$\mathrm{T}_{\mathrm{p}, \mathrm{t}}=$ Terynor Ratio, untuk portofolio $\mathrm{p}$, selama periode $\mathrm{t}$

$\mathrm{R}_{\mathrm{i}, \mathrm{t}}=$ Rata-rata return portofolio $\mathrm{p}$ selama periode $\mathrm{t}$

$\mathrm{PP}_{, \mathrm{t}}=$ Pertumbuhan Produksi selama periode $\mathrm{t}$

$\beta_{\mathrm{pt}}=$ Beta portofolio $\mathrm{p}$ selama periode $\mathrm{t}$

Dalam penelitian ini, angka Pertumbuhan Produksi (PP) menggunakan proxy indeks produksi pengolahan. Indeks produksi merupakan angka yang menggambarkan perkembangan produksi sektor industri pengolahan yang dihitung secara periodik bulanan. Jika angka indeks produksi menunjukkan perkembangan produksi industri pengolahan dibandingkan dengan periode dasar (tahun dasar $=100$ ), sedangkan angka Pertumbuhan Produksi (PP) adalah angka pertumbuhan dari indeks produksi dari waktu ke waktu yang dalam penelitian ini digunakan periode bulanan. Berdasarkan kerangka teoritik sebagaimana diuraikan di atas, maka hipotesis penelitian disusun sebagai berikut:

1) Semakin tinggi turnover ratio reksa dana syariah semakin tinggi kinerjanya;

2) Semakin tinggi expenses ratio reksa dana syariah semakin rendah kinerjanya;

3) Semakin tinggi fund size reksa dana syariah semakin tinggi kinerjanya;

4) Semakin tinggi fund age reksa dana syariah semakin tinggi kinerjanya;

5) Semakin tinggi fund selection reksa dana syariah semakin tinggi kinerjanya; 
ljtihad, Jurnal Wacana Hukum Islam dan Kemanusiaan, Volume 16, No. 2, Desember 2016: 217-236

\section{Metode}

Penelitian ini merupakan penelitian explanatory verificative yang bertujuan untuk menguji adanya hubungan sebab akibat antara variabel yang diteliti berdasarkan data empirik. Model ekonometrik yang digunakan adalah pooled datayaitu penggabungan antara data time series dan data cross sectional. Variabel - variabel yang dianalisis dalam penelitian ini adalah:

Tabel 1. Operasionalisasi Variabel-variabel Penelitian

\begin{tabular}{|c|c|c|c|c|}
\hline No. & Variabel & Konsep & Satuan & Skala \\
\hline 1 & $\begin{array}{c}\text { Kinerja } \\
\text { reksadana } \\
\text { syariah } \\
\text { (TREYNOR) }\end{array}$ & $\begin{array}{c}\text { Kemampuan reksa dana } \\
\text { menghasilkan return } \\
\text { dibandingkan dengan } \\
\text { risikonya. Pengukuran } \\
\text { kinerja yang sesuai adalah } \\
\text { mengyunakan Rasio Treynor. }\end{array}$ & Persen & Rasio \\
\hline 2 & $\begin{array}{l}\text { Turnover } \\
\text { ratio } \\
\text { (TORA) }\end{array}$ & $\begin{array}{c}\text { Rata-rata dari total penjualan } \\
\text { atau total pembelian dibagi } \\
\text { dengan total aktiva reksa } \\
\text { dana }\end{array}$ & Persen & Rasio \\
\hline 3 & $\begin{array}{l}\text { Expense } \\
\text { ratio } \\
(\mathrm{EXR \Lambda )}\end{array}$ & $\begin{array}{c}\text { Total dana yang digunakan } \\
\text { untuk biaya pengelolaan } \\
\text { reksa dana dibagi dengan } \\
\text { total Nilai } \Lambda \text { ktiva Bersih } \\
\text { (NAB). }\end{array}$ & Persen & Rasio \\
\hline 4 & $\begin{array}{l}\text { Fund } \\
\text { Size } \\
\text { (SIZE) }\end{array}$ & $\begin{array}{l}\text { Jumlah dana yang dikelola } \\
\text { oleh sebuah perusahaan reksa } \\
\text { dana yang diukur oleh } \log \\
\text { dari nilai total aktiva bersih }\end{array}$ & Rupiah & Rasio \\
\hline 5 & $\begin{array}{c}\text { Fund } \\
\text { Age } \\
\text { (FAGE) }\end{array}$ & $\begin{array}{l}\text { Lamanya perusahaan reksa } \\
\text { dana beroperasi yang diukur } \\
\text { oleh Log dari usia reksa dana }\end{array}$ & Bulan & Rasio \\
\hline 6 & $\begin{array}{l}\text { Fund } \\
\text { selection } \\
\text { (FSEL) }\end{array}$ & $\begin{array}{l}\text { Nilai koefisien } \gamma \text { pada model } \\
\text { l'reynor-Mazuy. Jika } \alpha= \\
\text { positif dan signifikan berarti } \\
\text { terdapal fund selection skill. } \\
\text { Variabel ini merupakan } \\
\text { dummy variable (D). }\end{array}$ & $\begin{array}{c}\mathrm{D}-0 \\
\text { tidak } \\
\text { terdapat } \\
\text { fund } \\
\text { selection } \\
\mathrm{D}=1 ; \\
\text { terdapat } \\
\text { fund } \\
\text { selection }\end{array}$ & Nominal \\
\hline
\end{tabular}


Data pokok yang diolah dan dianalisis dalam penelitian ini adalah data sekunder berupa data bulanan (monthly) periode Januari 2010 sampai dengan Desember 2013 (48 bulan). Alasan pemilihan data ini didasarkan pada pertimbangan bahwa pada periode ini keadaan perekonomian berada pada fase stabil (normal) dengan asumsi bahwa dampak krisis global (subprime mortage) yang terjadi tahun 2007 di Amerika Serikat sudah tidak berpengaruh pada perekonomian global termasuk di Bursa Efek Indonesia. Data yang digunakan dalam penelitian ini diperoleh dari Otoritas Jasa Keuangan (OJK), Bursa Efek Indonesia (BEI), Bank Indonesia (BI), Badan Pusat Statistik (BPS), dan publikasi lain yang relevan.

Perusahaan reksa dana yang dijadikan sampel dalam penelitian ini adalah perusahaan reksa dana yang tercatat di Bursa Efek Indonesia dan masih aktif diperdagangkan selama periode penelitian. Sampel penelitian ditentukan secara purposive, dengan kriteria:

1) Reksa dana syariah yang aktif diperdagangkan pada periode penelitian (bulan Januari 2010 sampai dengan bulan Desember 2013);

2) Menyampaikan laporan keuangan ke Otoritas Jasa Keuangan (OJK); dan

3) Memiliki data lengkap yang diperlukan selama periode penelitian.

Berdasarkan kriteria ini, maka reksa dana yang dijadikan sampel analisis dalam penelitian terdiri dari 27 reksa dana syariah yaitu:

1) Batavia Dana Saham Syariah; 2) CIMB- Principal Islamic Equity Growth Syariah; 3) Cipta Syariah Balance; 4) Cipta Syariah Equity; 5) Danareksa Syariah Berimbang; 6) Mandiri Amanah Syariah Protected Dollar Fund; 7) Mandiri Investa Atraktif-Syariah; 8) Mandiri Investa Dana Syariah; 9) PNM Amanah Syariah; 10) Trim Syariah Berimbang; 11) Trim Syariah Saham; 12) Danareksa Indeks Syariah; 13) Mandiri Investa Syariah Berimbang; 14) Manulife Syariah Sektoral Amanah; 15) Mega Dana Obligasi Syariah; 16) MNC Dana Syariah; 17) PNM Ekuitas Syariah; 18) PNM Syariah; 19) Sam Sukuk Syariah Sejahtera; 20) Sam Syariah Berimbang; 21) Syariah BNP Paribas Pesona Syariah; 22) Lautandhana Proteksi Syariah I; 23) AAA Amanah Syariah Fund; 24) BNI Dana Syariah; 25) BNI Danaplus Syariah; 26) Haji Syariah; 27) Schroder Syariah Balanced Fund. 
ljthad, Jurnal Wacana Hukum Islam dan Kemanusiaan, Volume 16, No. 2, Desember 2016: 217-236

Model penelitian disusun dalam persamaan sebagai berikut:

$$
\mathrm{Y}=\begin{aligned}
& \alpha+\beta_{1} \mathrm{TOR} \Lambda_{\mathrm{it}}+\beta_{2} \mathrm{EXR} \Lambda_{\mathrm{it}}+\beta_{3 \mathrm{Ln}} \mathrm{SIZE}_{\mathrm{it}}+\beta_{4} \operatorname{Ln} \cdot \mathrm{F} \Lambda \mathrm{GE}_{\mathrm{it}} \\
& \left|\beta_{5} \mathrm{DFSEL} L_{\mathrm{it}}\right| \varepsilon_{\mathrm{it}}
\end{aligned}
$$

dimana :

$\mathrm{Y}=$ Kinerja Reksa Dana Syariah (TREYNOR RATIO)

$\alpha=$ Intercept

$\beta_{\mathrm{i}} \quad=$ Koefisien korelasi masing-masing variabel

TORA $=$ Turnover Ratio

EXRA $=$ Expense Ratio

SIZE = Fund Size

$\mathrm{FAGE}=$ Fund Age

FSEL $=$ Fund Selection (Dummy Variable) D = 0; tidak terdapat Fund Selection, D = 1; terdapat Fund Selection

$\varepsilon_{\mathrm{it}} \quad=$ Error Term

Dalam melakukan analisis data panel (pooled data), terdapat dua metode regresi yang digunakan dalam analisis statistika, yaitu: Fixed Effects Model (FEM) dan Random Effects Model (REM). Uji Hausman dilakukan untuk memilih model terbaik dari kedua model tersebut. Uji hipotesis dilakukan baik secara simultan maupun secara parsial. Uji hipotesis secara simultan dilakukan terhadap hipotesis:

1. $\mathrm{H}_{0}: \beta_{\mathrm{i}}-0=$ Turnover ratio, expense ratio, fund size, fund ane, dan1 fund selection, tidak berpengaruh terhadap kinerja reksa dana syariah

$\mathrm{II}_{1}$ : Minimal = Turnover ratio, expense ratio, fund size, fund age, dan fund ada satu selection berpengaruh terhadap kinerja reksa clana $\beta_{\mathrm{i}} \neq 0 \quad$ syariah 
Sedangkan uji hipotesis secara parsial terhadap hipotesis-hipotesis sebagai berikut:

2. $\mathrm{H}_{0}: \beta_{\mathrm{i}} \leq 0=$ Tumover natio tidak berpengaruh positif terhadap kinerja rcksa dana syariah

$\mathrm{II}_{1}: \beta_{\mathrm{i}}>0 \quad-$ Turnower ratio berpengaruh positif terhadap kinerja reksa dania syariah

3. $\mathrm{H}_{\mathrm{u}}: \beta_{\mathrm{i}} \geq 0=$ Fxpenses matio ticlak berpengaruh negatif terhaclap kinerja reksa dana syariah

$\mathrm{H}_{1}: \quad \beta_{\mathrm{i}}<0=$ Expenses ratio herpengaruh nogatif terhadap kincrja reksa dana syariah

4. $H_{0}: \beta_{1} \leq 0=$ I'und size tidak berpengaruh positif terhadap kincrja reksa dana syariah

$\mathrm{II}_{1} \quad: \quad \beta_{\mathrm{i}}>0 \quad-$ Fund size berpengaruh positif terhadap kinerja relisa dana syariah

5. II $\quad$ I $\quad \beta_{\mathrm{i}}<0 \quad-\quad$ Fund age tidak berpengaruh positif terhadap kinerja reksa dana syariah

$\mathrm{H}_{1}: \quad \beta_{\mathrm{i}}>0=$ Fund age berpengaruh positif terhadap kinerja reksa dana syariah

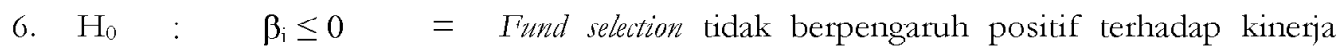
reksa dana syariah

$H_{1}: \quad \beta_{i}>0=$ linnd selection berpengaruh positif terhadap kinerja reksa dana syariah

\section{Pembahasan dan temuan}

Berdasarkan hasil uji Hausman model yang dipilih dan dianalisis dalam penelitian ini adalah Random Effect Model (REM). Hasil estimasi model dan beberapa parameter statistik disajikan oleh output hasil pengolahan data seperti disajikan pada Tabel 2. 
ljtihad, Jurnal Wacana Hukum Islam dan Kemanusiaan, Volume 16, No. 2, Desember 2016: 217-236

Tabel 2

Hasil Estimasi Random Effect Model (REM)

\begin{tabular}{|c|c|c|c|}
\hline Variabel & Koefisien & Prob. & $\begin{array}{l}\text { Hasil } \\
\left.\text { Uji }^{*}\right) \\
\end{array}$ \\
\hline C & -9.713526 & 0.0030 & Sig. \\
\hline TORA & 0.026591 & 0.0000 & Sig. \\
\hline EXRA & -0.811753 & 0.0000 & Sig. \\
\hline SIZE & 0.685542 & 0.0119 & Sig. \\
\hline FAGE & 1.011976 & 0.0383 & Sig. \\
\hline FSEI, & 5.195064 & 0.0000 & Sig. \\
\hline R-squared & 0.381643 & & \\
\hline
\end{tabular}

Sumber : Diolah dari Output E-Views 7 Hasil Pengolahan Data Penelitian, 2014 Ket: $*)=\alpha=5 \%$

Hasil uji hipotesis menunjukkan bahwa Prob (F-statistic) sebesar 0.0000 atau lebih kecil dari $\alpha=0.05$. Nilai Prob (F-statistic) dari yang lebih kecil dari nilai $\alpha=0.05$ menunjukkan terdapat pengaruh dari kelima variabel secara simultan terhadap kinerja reksa dana syariah dengan hasil uji yang signifikan. Hal ini berarti bahwa karakteristik reksa dana yang diwakili oleh variabel turnover ratio, expense ratio, fund size, fund age, dan fund selection secara simultan berpengaruh terhadap kinerja reksa dana syariah. Nilai R-squared $\left(\mathrm{R}^{2}\right)$ adalah sebesar 0.381643 yang berarti menunjukkan bahwa kelima variabel bebas TORA, EXRA, SIZE, FAGE dan FSEL mampu menjelaskan pengaruhnya terhadap variabel kinerja sebesar 38.16 persen sedangkan sisanya sebesar 61.84 persen lainnya dijelaskan oleh variabel lain yang tidak diteliti dalam penelitian ini.

Hasil uji hipotesis diketahui bahwa $p$-value variabel TORA sebesar 0.0000 atau lebih kecil dari $\alpha=0.05$. Nilai $p$-value dari yang lebih kecil dari nilai $\alpha=0.05$ menunjukkan terdapat pengaruh dari variabel TORA terhadap kinerja reksa dana syariah dengan hasil uji yang signifikan. Dilihat dari arah hubungannya, koefisien regresi variabel TORA menunjukkan angka positif $0.026591\left(\alpha_{i}>0\right)$ yang berarti terdapat hubungan positif variabel TORA terhadap kinerja reksa dana syariah. Fakta empirik hasil penelitian ini menunjukkan bahwa pada reksa dana syariah, turnoverratio secara signifikan berpengaruh positif terhadap kinerja reksa dana. 
Turnover ratio (TORA) merupakan perbandingan antara rata-rata penjualan dan pembelian dengan total aset yang dikelola oleh perusahaan reksa dana. Rasio ini digunakan untuk mengukur trading activity dari suatu portofolio. Angka perbandingan tersebut menggambarkan style Manajer Investasi dalam mengelola reksa dana, apakah aktif dan berorientasi jangka pendek atau berorientasi jangka panjang. Reksa dana yang mempunyai rasio perputaran (turnover ratio) yang sangat tinggi menunjukkan bahwa Manajer Investasi melakukan aktivitas pembelian maupun penjualan porofolio dengan frekuensi tinggi yang berarti menunjukkan tingginya trading activity reksa dana tersebut. Kinerja reksa dana yang baik terjadi pada reksa dana dengan trading activity yang tinggi. Semakin tinggi tingkat perputaran portofolio maka semakin tinggi return yang didapatkan. Tingginya turnover ratio menunjukkan bahwa Manajer Investasi benar-benar mengantisipasi perubahan pasar serta kondisi ekonomi yang kemudian akan mempengaruhi harga aset dalam portofolionya. Trading activity yang tinggi menggambarkan usaha Manajer Investasi dalam mewujudkan return yang maksimal dengan melakukan perdagangan pada saat yang tepat. Tingkat turnover yang tinggi atau dengan kata lain Manajer Investasi dengan gaya investasi aktif mewujudkan kinerja reksa dana yang lebih baik dibandingkan Manajer Investasi dengan gaya investasi pasif.

Hasil penelitian ini menunjukkan bahwa turnover ratio memiliki pengaruh yang positif terhadap kinerja reksa dana. Temuan ini sesuai dengan kesimpulan beberapa penelitian terdahulu yang memperoleh hasil bahwa turnover ratio memiliki pengaruh yang positif terhadap kinerja reksa dana (Grinblatt dan Titman, 1989;419). Reksa dana dengan high turnover menghasilkan kinerja yang lebih baik dan reksa dana dengan low turnover menghasilkan kinerja yang lebih buruk (Grinblatt dan Titman,1994;440,Anderson, et al., 1996;203, Cuthbertson, Nitzsche, dan O’Sullivan, 2010;95).

Hasil uji hipotesis variabel EXRA menunjukkan bahwa p-value sebesar 0.0000 atau lebih kecil dari $\alpha=0.05$. Nilai p-value yang lebih kecil dari nilai $\alpha=0.05$ menunjukkan terdapat pengaruh dari variabel EXRA terhadap kinerja reksa dana syariah dengan hasil uji yang signifikan. Dilihat dari arah hubungannya, koefisien regresi variabel EXRA menunjukkan angka $-0.811753\left(\alpha_{i}<0\right)$ yang berarti terdapat pengaruh negatif variabel EXRA terhadap kinerja reksa dana syariah. Fakta empirik hasil penelitian ini menunjukkan bahwa pada reksa dana syariah, expensesratio secara signifikan berpengaruh negatif terhadap kinerja reksa dana. Semakin 
ljtihad, Jurnal Wacana Hukum Islam dan Kemanusiaan, Volume 16, No. 2, Desember 2016: 217-236

tinggi expensesratio sebuah reksa dana syariah semakin rendah kinerja reksa dana tersebut.

Expenses ratio (EXRA) merupakan perbandingan antara beban operasional pengelolaan reksa dana dengan rata-rata nilai aset bersih (net asset value). Rasio ini menunjukkan seberapa besar pengorbanan investor dalam melakukan investasi pada reksa dana sekaligus menjadi indikasi seberapa "mahal" manajer investasi menetapkan tarif untuk mengelola reksa dana. Expenses ratio sebuah reksa dana adalah persentase total biaya yang digunakan untuk administrasi, manajemen, iklan, dan biaya-biaya lainnya. Expense ratio adalah biaya reksa dana dalam menjalankan kegiatan bisnisnya. Rasio ini penting menjadi perhatian saat investor akan memilih reksa dana karena besar kecilnya rasio ini akan turut menentukan besarnya return yang diterima oleh investor.

Biaya yang dikeluarkan perusahaan reksa dana untuk mengelola suatu investasi pada dasarnya adalah biaya yang harus dikeluarkan oleh investor. Biaya-biaya ini pada akhirnya akan mengurangi return dari investasi tersebut. Semakin besar biaya ini menunjukkan semakin rendah tingkat efisiensinya sehingga akan semakin kecil return yang akan diterima oleh investor. Hasil penelitian ini memperoleh fakta bahwa expense ratio berpengaruh negatif terhadap kinerja reksa dana. Temuan ini didukung oleh beberapa hasil penelitian terdahulu. Sharpe (1966;119) memperoleh temuan bahwa rasio biaya berbanding terbalik dengan kinerja reksa dana. Hasil penelitian Malkiel (1995;549) memperoleh bukti adanya hubungan yang negatif antara rasio biaya dengan kinerja reksa dana. Ciccotello dan Grant (1996;365) mengidentifikasi korelasi negatif antara ukuran aset dana dan rasio biaya. Carhart (1997;57) memperoleh kesimpulan bahwa rasio biaya berbanding terbalik dengan kinerja reksa dana.

Hasil uji hipotesis menunjukkan bahwa p-value variabel SIZE sebesar 0.0119 atau lebih kecil dari $\alpha=0.05$. Nilai p-value dari yang lebih kecil dari nilai $\alpha=0.05$ menunjukkan terdapat pengaruh dari variabel SIZE terhadap kinerja reksa dana syariah dengan hasil uji yang signifikan. Dilihat dari arah hubungannya, koefisien regresi variabel SIZE menunjukkan angka $0.685542\left(\alpha_{i}>0\right)$ yang berarti terdapat pengaruh yang positif variabel SIZE terhadap kinerja reksa dana syariah. Fakta empirik hasil penelitian ini menunjukkan bahwa pada reksa dana syariah, fund size secara signifikan berpengaruh positif terhadap kinerja reksa dana. Semakin tinggi fund size sebuah reksa dana syariah semakin tinggi pula kinerja reksa dana tersebut. 
Fund size (SIZE) menggambarkan besaran aset yang dikelola oleh perusahaan reksa dana. Besarnya aset ini menunjukkan seberapa besar kepercayaan (trust) dari investor kepada perusahaan reksa dana tersebut. Aktiva sebuah perusahaan merepresentasikan besaran kekayaan yang dimiliki perusahaan tersebut. Kekayaan reksa dana dapat dinilai dari besarnya NAB yang dimilikinya. Kekayaan yang dimiliki suatu perusahaan pada umumnya menunjukkan skala ekonomi perusahaan tersebut. Semakin besar skala ekonomi perusahaan maka semakin besar ukuran perusahaan tersebut. Besar kecilnya suatu reksa dana akan merepresentasikan jumlah kapitalisasi pasar reksa dana.

Hasil penelitian ini menunjukkan bahwa fund size secara signifikan berpengaruh positif terhadap kinerja reksa dana. Ini berarti bahwa reksa dana yang mengelola aset yang lebih besar akan memiliki kinerja yang lebih baik, karena selain menunjukkan tingkat kepercayaan investor yang besar terhadap reksa dana juga memiliki sumber daya yang mampu memberikan pelayanan lebih baik serta memiliki kekuatan tawar menawar yang lebih kuat sehingga dapat menghasilkan return yang lebih tinggi.

Besarnya dana kelolaan (fund size) dapat mempengaruhi kinerja suatu portofolio investasi. Dalam beberapa penelitian yang dilakukan untuk menginvestigasi pengaruh ukuran (size) terhadap excess return mengindikasikan bahwa ukuran perusahaan yang besar akan menyebabkan risiko yang dihadapi yang lebih kecil dibanding risiko yang dihadapi perusahaan yang lebih kecil (Chen, et al., 1992;659). Hasil penelitian Ciccotello dan Grant (1996;365) menunjukkan bahwa dana yang lebih besar (fund size) memiliki rasio biaya lebih rendah karena economics of scale. Abassi, Kalantari, dan Abassi. (2012;6889) melakukan penelitian untuk menguji pengaruh ukuran dana (fund size) terhadap kinerja reksa dana dan memperoleh temuan adanya hubungan yang signifikan antara ukuran dana (fund sizę) dengan kinerja reksa dana. Lebih lanjut, temuan hasil penelitian ini memvalidasi teori the economics of scale dalam reksa dana; semakin besar dana kelolaan (fund size) semakin rendah biaya yang harus ditanggung investor, sehingga return yang diperoleh akan semakin besar.

Hasil uji hipotesis menunjukkan bahwa p-value variabel FAGE sebesar 0.0383 atau lebih kecil dari $\alpha=0.05$. Nilai $p$-value dari yang lebih kecil dari nilai á $=0.05$ menunjukkan terdapat pengaruh dari variabel FAGE terhadap kinerja reksa dana syariah dengan hasil uji yang signifikan. Dilihat dari arah hubungannya, koefisien regresi variabel FAGE menunjukkan 
ljtihad, Jurnal Wacana Hukum Islam dan Kemanusiaan, Volume 16, No. 2, Desember 2016: 217-236

angka $1.011976\left(\alpha_{i}>0\right)$ yang berarti terdapat pengaruh yang positif variabel FAGE terhadap kinerja reksa dana syariah. Fakta empirik hasil penelitian ini menunjukkan bahwa pada reksa dana syariah, fund age secara signifikan berpengaruh positif terhadap kinerja reksa dana. Semakin tinggi fund age sebuah reksa dana syariah semakin tinggi pula kinerja reksa dana tersebut.

Fund age (FAGE) atauusia dari reksa dana menunjukkan berapa lama suatu reksa dana diperdagangkan di pasar modal. Reksa dana yang memiliki umur yang lebih lama akan memiliki track record yang lebih panjang, maka dari itu akan dapat memberikan gambaran kinerja yang lebih baik kepada para investornya. Umur reksa dana mencerminkan pengalaman dari manajer investasinya di dalam mengelola reksa dana tersebut. Semakin lama umur suatu reksa dana, maka manajer investasinya semakin berpengalaman di dalam mengelola portofolio bila dibandingkan dengan reksa dana yang berumur lebih muda.

Para investor pada umumnya memiliki kecenderungan untuk berinvestasi pada reksa dana yang sudah beroperasi lebih lama dibandingkan dengan memilih reksa dana yang baru terbit atau perusahaan reksa dana yang baru beroperasi. Reksa dana yang sudah beroperasi lama dapat mendorong tumbuhnya kepercayaan investor terhadap kemampuan dan track record manajer investasinya. Khorana dan Nelling (1998;61) melakukan penelitian dengan menggunakan multinomial probit model dan berhasil mengidentifikasi bahwa kinerja reksa dana yang baik memiliki manajer investasi yang mempunyai pengalaman lebih lama. Afza dan Rauf (2009;199) melakukan penelitian untuk mengkaji efektivitas pengelolaan reksa dana dan memperoleh temuan bahwa reksa dana dengan risk-adjusted return yang positif berhubungan dengan umur reksa dana tersebut. Peningkatan usia reksa dana memungkinkan dana untuk mencapai efisiensi operasional.

Hasil uji hipotesis variabel FSEL menunjukkan bahwa $p$-value sebesar 0.0000 atau lebih kecil dari $\alpha=0.05$. Nilai $p$-value dari yang lebih kecil dari nilai $\alpha=0.05$ menunjukkan terdapat pengaruh dari variabel FSEL terhadap kinerja reksa dana syariah dengan hasil uji yang signifikan. Dilihat dari arah hubungannya, koefisien regresi variabel FSEL menunjukkan angka $5.195064\left(\alpha_{i}>0\right)$ yang berarti terdapat pengaruh yang positif variabel FSEL terhadap kinerja reksa dana syariah. Fakta empirik hasil penelitian ini menunjukkan bahwa pada reksa dana syariah, fund selection secara signifikan berpengaruh positif terhadap kinerja reksa dana. 
Semakin tinggi fund selection sebuah reksa dana syariah semakin tinggi pula kinerja reksa dana tersebut.

Fund Selection menggambarkan kemampuan manajer investasi untuk memilih aset untuk membentuk portofolio yang diprediksi akan memberikan return yang diharapkan di masa yang akan datang. Manajer investasi lebih sering mengandalkan kemampuan pemilihan sekuritas untuk mendapatkan return yang abnormal (superior).

Temuan hasil penelitian ini mendukung kesimpulan hasil penelitian Fama (1972;551) yang mengembangkan metode untuk membedakan return sebagai akibat dari kemampuan fund selection pada tingkat risiko tertentu dengan cara memprediksi pergerakan harga pasar dan menyampaikan argumen adanya keterkaitan antara return portofolio dengan fund selection. Hasil penelitian Kon dan Jen (1979;261) juga menunjukkan bahwa secara statistik keseluruhanstock selection berpengaruh positif signifikan padakinerja23 reksa dana. Treynor dan Mazuy (1966;131) menemukan bukti bahwa peningkatan return disebabkan oleh kemampuan fund manager untuk mengidentifikasi harga.

\section{Penutup}

Penelitian ini memperoleh kesimpulan bahwa secara simultan terdapat pengaruh karakteristik reksa dana yang terdiri dari turnover ratio, expenses ratio, fund size, fund age, dan fund selection terhadap kinerja reksa dana syariah. Besarnya pengaruh variabel karakteristik terhadap kinerja reksa dana syariah sebesar 38.16 persen.

Turnover ratio, fund size,fund age, dan fund selection atau kemampuan manajer investasi melakukan portofolio aset berpengaruh positif terhadap kinerja reksa dana syariah, semakin tinggi keempat variabel ini semakin tinggi kinerja reksa dana syariah. Sedangkan expenses ratio berpengaruh negatif terhadap kinerja reksa dana syariah, semakin tinggirasio biaya atau expenses ratio semakin rendah kinerja reksa dana syariah. Untuk mengembangkan penelitian ini, disarankan agar penelitian lanjutan melakukan penambahan variabel dalam model penelitian, seperti faktor gender Manajer Investasi atau faktor-faktor yang bersifat makro seperti tingkat inflasi.

Bagi perusahaan reksa dana syariah (Manajer Investasi) disarankan untuk melakukan (1) trading activity portofolio dengan frekuensi yang tinggi, dan (2) melakukan pemilihan aset 
ljtihad, Jurnal Wacana Hukum Islam dan Kemanusiaan, Volume 16, No. 2, Desember 2016: 217-236

(fund selection) secara selektif, dan (3) mengupayakan efisiensi biaya pengelolaan (expenses ratio), guna meningkatkan kinerja reksa dana syariah yang dikelolanya. Kinerja reksa dana yang baik akan mendorong munculnya kepercayaan (trust) dari para investor sehingga dana kelolaan (fund size) akan meningkat. Besarnya dana kelolaan (fund size) pada akhirnya juga akan meningkatkan kinerja reksa dana. Bagi para investor disarankan untuk memilih reksa dana yang memiliki (1) usia perdagangan (fund age) yang sudah lama, dan (2) dana kelolaan (fund size) yang besar. Reksa dana yang memiliki kedua karakteristik ini terbukti memiliki kinerja yang lebih baik dibandingkan dengan reksa dana yang baru diperdagangkan serta dibandingkan dengan reksa dana yang memiliki dana kelolaan yang kecil.

\section{Daftar pustaka}

Abbasi, Majid, Elham Kalantari, Hamideh Abbasi. "Effect of Fund Size on The Performance of Mutual Fund; Evidence from Iran", dalam Journal of Basic and Applied Scientific Research, 2 (7), 2012: 6889-6902.

Afza, Talat and Rauf Ali. "Performance Evaluation of Pakistani Mutual Funds", dalam Pakistan Economic and Social Review Volume 47, No. 2 (2009): 199-214.

Anderson, S.B., D. Coleman, Gropper and Sunquist H. "A Comparison of The Performance of Open and Closed End Investment Companies", dalam Journal of Economic and Finance (1996): 203-211.

Badan Pengawas Pasar Modal dan Lembaga Keuangan Departemen Keuangan (BapepamLK) RI. Factbook, 2010-2013.

Benny Kurniawan, Hermanto Siregar, dan TriasAndati. "Market Timing, Selektivitas Saham serta Kinerja dari Produk Reksa Dana Saham di Indonesia, dalam Jurnal Aplikasi Bisnis dan Manajemen Vol. 2 No. 1 (2016): 43-52.

Cana Paranita, Moch. Dzulkirom, AR., Raden Rustam Hidayat. "Analisis Kinerja Investasi Dalam Reksadana Saham (Equity Funds) dengan Metode Sharpe dan Treynor", dalam Jurnal Administrasi Bisnis (JAB) Vol. 27 No. 1 (2015): 1-7.

Carhart, M. M., "On Persistance in Mutual Fund Performance”, dalam Journal of Finance Vol. 52 No.1 (1997): 57-82.

Chen, C., F. Cheng, S. Rahman and A. Chan. "Cross Sectional Analysis of Mutual Fund's Market Timing and Security Selection Skill”, dalam Journal of Business Finance and Accounting Vol. 19 (1992): 659-674.

Ciccotello, Conrad S., and Grant C. Terry. "Equity Fund Size and Growth: Implications for Performance and Selection”, dalam Financial Services Review Vol. 5 No.1 (1996): 365380. 
Cuthbertson, Keith, Dirk Nitzsche and Niall O'Sullivan. "Mutual Fund Performance: Measurement And Evidence", dalam Journal of Financial Markets, Instruments and Institutions Vol. 19 No.2 (2010): 95-187.

Denny Hermawan dan Ni Luh Putu Wiagustini. "Pengaruh Inflasi, Suku Bunga, Ukuran Reksa Dana, Dan Umur Reksa Dana Terhadap Kinerja Reksa Dana”, dalam E-Jurnal Manajemen Unud Vol. 5, No. 5, 2016.

Eric Marshall Ting ToyodanSylviana Maya Damayanti. “Trade-off Study of Equity Mutual Fund for Small and Medium Enterprise", dalam Procedia - Social and Behavioral Sciences Vol. 169 (2015): 249-257.

Fama, E., "Component of Investment Performance", dalam Journal of Finance Vol. 27, No.3 (1972): 551-567.

Friend, Blume, Crockett. "Mutual Funds and Other Institutional Investors - A new perspective”. New York: Mc Graw Hill Book Company 1970.

Friend, I., F. Brown E. Herman, and D. Vickers. "A Study of Mutual Funds", dalam US Securities and Exchange Commission. Washington DC: US Government Printing Office, 1962.

Grinblatt, M., and Sheridan Titman. "Mutual Fund Performance; An Analysisi of Quarterly Portfolio Holdings", dalam Journal of Financial and Quantitative Analysis Vol. 62, No. 3 (1989): 393-416.

Grinblatt, Mark, and Sheridan Titman, 1994. "A Study of Monthly Mutual Fund Returns and Performance Evaluation Techniques". The Journal of Financial and Quantitative Analysis, 29 (3), 419-444.

Hair, Joseph F.. "Multivariate Data Analysis". Fourth Editions; Prentice-Hall, United States of America, 1995.

Indro, D.C., Hu Jiang C.X., Lee, W.Y. "Mutual Fund Performance; Does Size Matter?”, dalam Financial Analysis Journal Vol. 55, No.3 (1999): 74-87.

Jensen, Michael C. "The Performance of Mutual Funds in the Period 1945-1964", dalam The Journal of Finance Vol. 23 (1968): 389-416.

Kartini dan Rico Febriyanto. "Analisis Perbandingan Kinerja Reksa Dana Konvensional dengan Kinerja Reksa Dana Syariah", dalam Jurnal Bisnis dan Ekonomi Vol. 2, No 1 (2011): 1-16.

Khorana, Ajay and Edward Nelling. "The Determinants And Predictive Ability of Mutual Fund Ratings”, dalam Journal of Investing Vol. 7 No. 3 (1998): 61-66.

Kon, S. and F. Jen. "The Investment Performance of Mutual Funds: An Empirical Investigation of Timing, Selectivity and Market Efficiency", dalam Journal of Business Vol. 63 (1979): 261- 278. 
ljtihad, Jurnal Wacana Hukum Islam dan Kemanusiaan, Volume 16, No. 2, Desember 2016: 217-236

Kon, S. "The Market Timing Performance of Mutual Fund Managers", dalam Journal of Business Vol. 56 (1983): 321-347.

Low, Soo-Wah. "Relationship Between Fund Performance and Characteristic of The Malaysian Unit Trust Fund", dalam Singapore Management Review Vol.32, No.1 (2010): 2943.

Malkiel, B. "Return from Investing in Equity Mutual Fund: 1971-1991", dalam The Journal of Finance Vol. 50 (1995): 549-572.

Sharpe, William F. "A Theory of Market Equilibrium under Conditions of Risk", dalam The Journal of Finance Vol.19, No.3 (1964): 425-442.

Sharpe, William F. "Mutual Fund Performance", dalam Journal of Business Vol. 39, No.1 (1966): 119-138.

Tandelilin, Eduardus. Portofolio dan Investasi, Teori dan Aplikasi. Yogyakarta: Kanisius, 2010.

Treynor, J. and K. Mazuy. "Can Mutual Funds Outguess the Market?, dalam Harvard Business Review Vol. 44 (1966): 131-136.

Treynor, J., and F. Black. "How to Use Security Analysis to Improve Portfolio Selection", dalam Journal of Business Vol. 46, No. 1 (1973): 66-86.

Treynor, Jack, "How to Rate Management of Investment Funds", dalam Harvard Business Review Vol. 43 No.1 (1965): 63-73.

Undang-undang Republik Indonesia Nomor 8 Tahun 1995 tentang Pasar Modal. 